\title{
Theoretical foundation of military translation in Ukraine
}

\author{
V. V. Balabin \\ Taras Shevchenko National University of Kyiv, Ukraine \\ Corresponding author. E-mail: vitor.balabin@gmail.com \\ Paper received 05.08.18; Accepted for publication 13.08.18.
}

https://doi.org/10.31174/SEND-Ph2018-176VI51-05

\begin{abstract}
Being a special branch of translation studies or translatology, the military translation theory does not stand out today as a complete set of summarized facts, hypothetical principles, theoretical judgments and methodological provisions, coherently integrated into one consolidated system. On the contrary, it lacks many units of its conceptual construct, which should encompass not only the traditional realm of military translation and interpreting, but also the entire domain of the linguistic support for forces. As such, the military translation theory does not hold its theoretical foundation that ought to substantiate the essence and specificity of the military interpreter's professional duties and tasks. The author focuses on key elements and specific features of military translation theory that present its conceptual construct and lay its theoretical foundation.
\end{abstract}

Keywords: translation studies, military translation, military translation theory, conceptual construct, terminology, definition.

Introduction. Military translation is traditionally understood as "a type of special translation with a clearly manifested military communication function" [1, p. 13] or "a type of special translation for operational purpose, the object of which are military materials." [2, p. 222]. Although the systematic theoretical studies and research of military translation started in the middle of the last century, the theory of military translation, being a special branch of translation studies or translatology, unfortunately, does not stand out today as a complete set of summarized facts, hypothetical principles, theoretical judgments and methodological provisions, coherently integrated into one consolidated system. On the contrary, it lacks many units of its conceptual construct, which should encompass not only the traditional realm of military translation and interpreting, but also the entire domain of the linguistic support for forces. As such, the military translation theory does not hold its theoretical framework that ought to substantiate the essence and specificity of the military interpreter's professional duties and tasks.

Literature overview. The theoretical research of military translation began in the Former Soviet Union (FSU) in the early 1960s with the published works of L.L. Nelyubin, and continued in the 1970-80s by A.D. Shvejtser, G.M. Strelkovskij, R.K. Min'yarBeloruchev, G.A. Sudzilovskij, M.Ya. Tsvilling, L.K. Latyshev V.N. Shevchuk and others.

After the disintegration of the FSU in 1991, the studies and research of military translation resumed in newly independent countries. In Russia, Andreev N.I., Ahtambaev R.P., Banman P.P., Boyko B.L., Bondarenko N.L., Borisova L.I., Bushev A.B., Gavrilov L.A., Garbovskij N.K., Degtyarenko K.A., Dmitrieva Yu.S., Dubrova Yu.Yu., Zagaynov S.S., Kataev A.O., Knyazeva E.G., Kopreva L.G., Kurapova E.A., Lushev E.P., Maltseva O.L., Mescheryakova O.V., Mitchell P.D., Mishkurov E.N., Soldatova D.N., Torsukov E.G. and others published articles on different theoretical aspects of military translation. The most substantial paper, in our opinion, is presented by N.K. Garbovskij and E.N. Mishkurov [3].

In Ukraine, V.V. Balabin, P.A. Matyusha, M.B. Bilan, S.Ya. Yanchuk., B.A. Dzys, O.V. Yundina, and L.M. Goncharuk defended PhD dissertations in the field of military translation. For a fuller overview of the re- searched topics and problems of military translation, see Balabin [4].

Unfortunately, the concept, term or entry of military translation is absent in the most comprehensive translation studies' sources - both editions of the Routledge Encyclopedia of Translation Studies [5-6], the fourvolume Benjamin's Handbook of Translation Studies [7], and the Oxford Handbook of Translation Studies [8].

Therefore, the analysis of publications on military translation for the period of 1964-2017 shows that many fundamental concepts of the military translation theory are neither theoretically substantiated, nor terminologically defined.

The purpose of the article is to present key elements of the military translation theory that constitute its conceptual construct and lay its theoretical foundation, based on Ukraine's experience.

Material and methods. Materials of the research were monographs, dissertations, scientific articles, textbooks, study guides, various professional and encyclopedic publications, reference books, dictionaries and glossaries. To prove theoretical judgments, hypothetical conclusions and methodological provisions, the author widely used official administrative and academic documents of the Military Institute of Taras Shevchenko National University of Kyiv for the period of 1998-2016. These were final reports of the state examination and qualification boards; commandant's administrative and academic orders; annual, periodic and thematic analytical materials of different boards, commissions and councils; survey materials and questionnaires; official evaluation reports of military interpreters' performance, submitted to the Military Institute by unit commanders, etc.

The author widely applied general scholarly and philosophical methods of abstraction, idealization, extrapolation, analysis, synthesis, comparison, hypotheses, generalization, structural analogy, typology, definition analysis, etc. to create, compare and/or clarify different verbal models - concepts, terms and definitions that make up military translation theory's abstract construct and terminological framework, and to give a critique of the existing views and definitions.

Results and discussion. One of the main problems of the military translation theory today is "to identify, define, normalize, and standardize basic terms and definitions of its conceptual construct" [9, p. 107]. Let us analyze key 
elements of the military translation theory's conceptual construct that lay its theoretical foundation.

Definition of military translation. Experts of the European Master's Translation project [10] noted, that "the term "translation" itself has come to be ambiguous: sometimes it is taken to mean word-for-word transfers (e.g. "pocket translations" which are only lexical correspondence dictionaries, devoid of context), sometimes it includes localisation (of software, websites, video games), versioning (of audiovisual documents), transediting (of information from press agencies, newspapers, television reports), multilingual and technical writing, adaptation (of advertising), revision, summary translation, etc. ... It is difficult to anticipate all the changes still to come in the next 20-30 years (for example, software enabling the transfer from oral to written and written to oral), even though the students undergoing training will still be in the labour markets. " [10, p. 2].

The concept/term of military translation belongs to the headmost units of the military translation theory's conceptual construct that require proper clarification and definition. The "Explanatory translation studies' dictionary" by L.L. Nelyubin [11] - one of the most comprehensive academic and reference publications in Russian that contains 2,028 entries extracted from 224 sources - registers two definitions of military translation:

"1. A type of special translation with a clearly manifested military communication function. A distinctive feature of the military translation is the heavy terminological saturation and extremely precise, clear presentation of the materials with the relative absence of figurative and emotional expressive means. 2. A type of special translation for operational purpose, the object of which are military materials." [11, p. 32].

The first version of the definition belongs to L.L. Nelyubin, who used it in the preface to the textbook on military translation in 1972 [1, p. 13], and the second version is authored by R.K. Min'yar-Beloruchev [2, p. 222]. Even though Min'yar-Beloruchev's definition looks better (more precise and concise), both definitions do not explicate well enough the nature and specificity of military translation, and, unfortunately, lead to a "vicious circle" - define the term by the same definition: "military translation is a type of special translation...".

With due respect to both distinguished authors, we would like to offer our definition for the term/concept of military translation, bearing in mind that for scientific, educational, methodological and practical purposes it is preferable to have concise and expanded definitions.

The concise definition demonstrates only predominant features of military translation, and simultaneously makes it possible to differentiate military translation from other translation types and translatology concepts. It also meets the requirements of rational and operational brevity - an essential prerequisite for terminology definitions. Military translation - a special type of mediated intercultural communication, carried out for the linguistic support of the armed forces.

The expanded definition explicates additional indispensable features of military translation. It presents the term/concept of military translation as a complex system having integral structural elements. It also reveals military interpreter's role and functions. Military translation $-a$ special type of mediated, intercultural, bilateral and bilingual communication, which has military-general, military-political, military-technical and military-special texts as its object, and is carried out under normal and extreme conditions of military service through a professional military interpreter.

Object of military translation. We see the object of military translation as its distinguishing trait or fundamental characteristics. It ensures ample perception and unambiguous understanding of the terminological definition of military translation According to R.K. Min'yarBeloruchev, military materials comprise the object of military translation: "Military translation. A type of special translation for operational purpose, the object of which are military materials." [2, p. 222].

N.K. Garbovskij and E.N. Mishkurov identify " $\underline{m i l i-}$ tary parlance" (professional military speech and/or discourse") as the object of military translation: "As its object, military translation has the so-called "military parlance" - all those speech products that are generated by the military or for the military under specific communication conditions. Thus, military parlance can be regarded as a specific form of language communication, inherent in a particular professional community, united by the common object of its activities." [3, p. 17].

According to our definition of military translation, $\underline{\text { mil- }}$ itary-general, military-political, military-technical and military-special texts constitute the object of military translation.

Subject of military translation. Another concept that calls for consideration is the subject (or subject matter) of military translation. In our opinion, the subject, much like the object, is another fundamental abstract feature of military translation theory, which hypothetically explains the ontological essence or general subject of its specificity, characteristic features and qualities. Since there is no available definition for this concept, it is convenient to have a shorthand notation, which will succinctly describe the subject (subject matter) of military translation. To a first approximation, we may regard mediated intercultural and bilateral communication in the armed forces as the subject of military translation, which is accordingly reflected and represented in our definition of military translation.

Methodology of the military translation theory is " $a$ set of theoretical provisions that reveal the principles, methods, and techniques for constructing, describing and applying typical algorithms for the military interpreter's operational activities. " [4, p. 13].

Military translation theory. The concept/term "military translation theory" should inherently comprise and systematize both general scientific, linguistic and translatological concepts of scholarly discourse as well as specific categories. General abstract concepts naturally enable military interpreters to understand the essence of the fundamental theoretical/hypothetical units, use them in research and cognitive activities, make their own references and conclusions, integrate them into appropriate theoretical systems.

According to L.L. Nelyubin "the theory of military translation is comprehensively presented in the works of G.M. Strelkovskij" [11, p. 220]. However, you will not find a definition for the concept/term "military transla- 
tion theory" in G.M. Strelkovskij's profound monograph "Theory and practice of military translation" [12], Nelyubin's dictionary [11] or other publications on military translation. Therefore, to fill the existing gap in military translation's conceptual construct, the following definition of the military translation theory seems adequate:

"Military translation theory - a group of wellstructured and summarized facts, theoretical judgments, hypotheses and methodological provisions, coherently integrated into one system by carefully selected and terminologically refined units of its conceptual construct, which reveal the essence and specificity of the military interpreter's professional duties" [13, p. 99].

Furthermore, the concept/term "military translation theory" inevitably leads to subsequent definitions of interrelated concepts/terms - "object of the military translation theory" and "subject of the military translation theo$r y$ ", which we are going to specify hereinafter.

The object of military translation theory encompasses not only the traditional realm of military translation and interpreting, but also the entire domain of the linguistic support for forces [13, p. 99].

The subject of the military translation theory - creation of abstract verbal, graphic, mathematical and other models that construe and explicate translation and interpreting process for the armed forces [13, p. 99].

Military translation theory's mission and problems. The subject of the military translation theory determines its main mission - the accumulation of plausible and scientifically acceptable knowledge on military translation - facts, principles, abstract judgments, hypothetical conclusions, arguments, concepts, terms, and definitions, which are coherently integrated into one consolidated system, in synergy with translation studies, military science, other related and integrated sciences.

The main problems of the military translation theory are as follows:

- to explore its fundamental scholarly principles (general-scientific, philological-linguistic, translatological, interdisciplinary, vocational/specific);

- to specify its place and role in the translation studies (translatology);

- to study its interdisciplinary ties;

- to identify, study, and define military translation's characteristic features, fundamental qualities and concepts (object, subject, units, terms, definitions, etc.);

- to examine its genre-stylistic and functionalpragmatic specificity;

- to research, generalize and systematize its methodological basis (strategy, tactics, technology of military interpreter's operational activities, etc.);

- to study lexical-semantic and structural-syntactic specificity of military translation;

- to construe the content and structure of the military interpreter's professional competence;

- to determine the content and structure of the linguistic support for forces;

- to explore the functions and tasks of the military interpreter's service duties and activities;

- to formulate demands and requirements for the military interpreter's professional culture and etiquette;
- to study and research psycholinguistic and psychophysiological aspects of the military interpreter's professional activities;

- to explore the specificity of military translation and linguistic support for forces in other countries;

- to normalize and standardize basic terms and definitions of its conceptual construct [9, p. 106-107].

Conceptual construct of the military translation theory. The translation theory's hypothetical framework can analyzed at four levels: philosophical/scholarly, philological/linguistic, translatological, and specialized (vocationally specific). For example, the military translation theory's discourse will inevitably include the following types of categorical units - concepts, elements, terms, definitions:

(1) general philosophical/scholarly (e.g., theory; object; subject; method; analysis, etc.);

(2) general philological/linguistic (e.g., language; communication; speech; discourse; text, etc.);

(3) general translatological (e.g., translation; interpreting; translation theory; scopos; target text; adequacy; equivalence, etc.);

(4) specialized (vocationally specific) (e.g., military translation; linguistic support for forces; military interpreter, etc.).

Thus, the conceptual construct of the military translation theory - meta-language, represented by its specialized (vocationally specific) categorical units concepts, elements, terms and definitions - that form the military translation theory's hypothetical framework.

Linguistic support for forces. This concept is also fundamental for the military translation theory's construct [14]. It constitutes the object of the military translation theory, as we have shown earlier. Based on our experience, it possible to give the following definition for the concept/term:

Linguistic support for forces - a complex of special measures, tasks, procedures and processes of practical and fundamental nature in the military-political, militarytechnical and military-special fields of the Armed Forces of Ukraine, which are planned and carried out to accomplish intercultural (communicative \& mediational), linguo-geographical (informational \& analytic), militaryterminological (normative \& codifying), linguopedagogical (didactic \& diagnostic) and linguo-research (scholarly) functions that require military-professional level of bilingual philological competence of performers [14, p. 144-145].

Accordingly, the object of the linguistic support for forces encompasses measures, tasks, procedures and processes in the military-political, military-technical and military-special fields of the Armed Forces of Ukraine that require military-professional level of bilingual philological competence of performers [15, p. 102].

Consequently, the subject of the linguistic support for forces incorporates military translator's/interpreter's communicative-mediational, linguo-geographical, military-terminological, linguo-pedagogical and linguoresearch missions. [15, p. 102].

Henceforth, the military interpreter/translator is the principal actor of the linguistic support for forces [15, p. 102]. 
At this point, it is worthwhile to consider briefly the concept of "translation and/or interpretation for the armed forces" and the concept of "military interpreter/translator".

Translation/interpretation (T/I) for the armed forces constitutes the core of the linguistic support for forces. A more precise definition is as follows:

"Translation/interpretation (T/I) for the armed forces - the main component of the linguistic support for forces, which boils down to intercultural and bilateral communication in the form of oral, written, sequential and simultaneous mediation, adapted transcoding (retelling, narration), referencing, editing and annotation of militarygeneral, military-political, military-technical and military-special texts. " [4, p. 13].

Military interpreter/translator. As we have shown earlier, the military interpreter/translator is a "principal actor" of the linguistic support for forces, which can be used as a concise definition. The expanded definition explicates military interpreter's role, additional indispensable qualities and competences:

Military interpreter/translator - the principal actor of the linguistic support for forces, an officer-philologist, who possesses bilingual communicative (mainly mediatory and intercultural), cognitive, psycholinguistic and other generic and specific professional competencies to perform his/her functions and duties under normal and extreme conditions of military service.

Translation/interpretation for the military has always been risky and dangerous. "The Armed Forces Journal reported in 2011 that interpreters in Iraq were "10 times more likely to die in combat than deployed American or international forces." [16]. Therfore, we strongly believe that translation/interpretation for the military has to be done by the military (not civilian!) men and women.

Conclusion. The analysis of publications on military translation for the period of 1964-2017 shows that the military translation theory lacks many units of its conceptual construct, which should encompass not only the traditional realm of military translation and interpreting, but also the entire domain of the linguistic support for forces. As such, the military translation theory does not hold its theoretical foundation that ought to substantiate the essence and specificity of the military interpreter's professional duties and tasks. The presented military translation theory's concepts, terms and definitions form its theoretical foundation in light of the author's experience (19822017) in practicing, teaching, and researching military translation.

\section{REFERENCES}

1. Nelyubin L.L. Military translation and its specificity [Voennyj perevod i ego osobennosti]. Military translation textbook: English / A.A. Dormidontov, L.L. Nelyubin, A.A. Vasilchenko. Moscow: Military Publishing House [Voenizdat], 1972. P. 13-37.

2. Min'yar-Beloruchev R.K. General theory of translation and interpretation [Obshhaya teoriya perevoda i ustnyj perevod]. Moscow: Military Publishing House [Voenizdat], 1980. 237p.

3. Garbovskij N.K., Mishkurov E.N. Military translation in the modern world (theoretical-methodological, linguistic, military-historical and socio-political aspects) [Voennyi perevod v sovremennom mire (teoretiko-metodologicheskie, lingvisticheskie voenno-istoricheskie i sotsialno-politicheskie aspekty)]. Herald of the Moscow University. Series 22: Theory of Translation. 2010. No. 2. P. 16-41.

4. Balabin V.V. Theoretical and conceptual framework for military translation [Teoretyko-kontseptualni osnovy viiskovoho perekladu]. Philological treatises [Filolohichni traktaty] Vol. 10. № 1, 2018. P. 7-18. DOI: 10.21272 / Ftrk.2018.10 (1) -01.

5. Routledge Encyclopedia of Translation Studies (1998). Ed. by Mona Baker. London \& New York: Routledge, $654 \mathrm{p}$.

6. Routledge Encyclopedia of Translation Studies (2011). Mona Baker and Gabriela Saldanha (eds.). Taylor \& Francis Group, 2nd ed., xxii +674 p.

7. Handbook of Translation Studies. Gambier Y., Van Doorslaer L. (eds.). Amsterdam and Philadelphia, PA; John Benjamins Publishing Company. Vol. 1 (2010), ix + 458 p; Vol. 2 (2011), x + 197 p.; Vol. 3 (2012), xii + 220 p.; Vol. 4 (2013), $\mathrm{xii}+232 \mathrm{p}$.

8. The Oxford handbook of translation studies (2011). Malmkjær, Kirsten, and Kevin Windle (eds.). Oxford: Oxford University Press, xvii +607 p.

9. Balabin V.V. The problems of the military translation theory [Zavdannia teorii viiskovoho perekladu]. Philology and linguistics in modern society [Filolohiia i linhvistyka $v$ suchasnomu suspilstvi]. Materials of the V International Scientific and Practical Conference (Khmelnytsky, March 23-24, 2018). Kherson: Publishing House "Helvetica", 2018. P. 105-107.

10. EMT 2009 expert group. Competences for professional translators, experts in multilingual and multimedia communication (updated 5 May 2017). 8 p. Retrieved from https://ec.europa.eu/info/sites/info/files/emt_competences_tra nslators_en.pdf.

11. Nelyubin L.L. Explanatory translation studies' dictionary [Tolkovyj perevodovedcheskij slovar']. 5th ed. Moscow: Flinta: Science, 2008. 320 p.

12. Strelkovskij G.M. Theory and practice of military translation: German language [Teoriya i praktika voennogo perevoda: Nemetskij yazyk]. Military Publishing House [Voenizdat], 1979. $272 \mathrm{p}$.

13. Balabin V.V. Object and subject of the theory of military translation [Ob'iekt i predmet teorii viiskovoho perekladu]. Scientific Herald of the International Humanitarian University. Series: Philology. 2017. No. 31. Volume 3. P. 97100.

14. Balabin V.V. The concept of the linguistic support for forces. Paradigm of Knowledge. № 2 (28), 2018. P. 144-154. DOI 10.26886/2520-7474.2(28)2018.10.

15. Balabin V.V. Object, subject and tasks of linguistic support for forces [Ob'iekt, predmet i zavdannia linhvistychnoho zabezpechennia viisk]. Scientific Herald of Kherson State University. Series: Translation Studies and Intercultural Communication. Issue 1. Volume 2, 2018. P. 99-102.

16. Polizzotti, Mark. Why Mistranslation Matters. The New York Times. July 29, 2018, P. SR10. 